Original articles

J. Perinat. Med. $11(1983) 232$

\section{Fetal response to external mechanical stimuli}

\author{
E.P. Issel
}

Department of Obstetrics and Gynecology, Martin-Luther-University, Halle-Wittenberg (Director: Prof.Dr.med.habil.W. Helbing)
When recording external fetal CTG, the nonstress test is negative in about 20 to $40 \%$ of the recordings during the first 20 minutes $[12,14]$.

In those cases one must distinguish between physiological non REM sleep (NREM) of the fetus and a nonreactive pathological CTG. Three different methods have been recommended to differentiate these two states.

1. Recording time of the CTG is prolonged until the spontaneous sleep-arousal state has changed in the fetus and until the fetus has become more active.

2. A load is placed on the fetus, e.g. induction of labor during an oxytocin test.

3. External mechanical stimulation of the fetus via the abdominal wall of the mother which is expected to arouse the fetus $[1,3,12]$.

FISCHER [3] states that by palpitations during limited undulating or silent CTG the sleeping fetus can be "aroused". Should the oscillation amplitude (macrofluctuation, prolonged variability) not increase after such a stimulus, the fetus is judged to be seriously impaired. LEE et. al. [8] also consider a lack of increase in motor activity in response to mechanical stimulation to be a pathological sign.

RICHARDSON et al. [14], on the other hand, recorded the CTG for 90 minutes and then applied a standardized mechanical stimulus for 30 seconds followed by a further 90 minutes of recording in 14 normal pregnancies. Another 3 fetuses in normal pregnancies were mechanically stimulated every 15 minutes for 3 hours. Except when extremely strong stimuli were applied, they found no changes in the oscillation amplitude of the CTG, no changes in fetal movements, in the number of respiratory movements or the duration of respiration. They conclude that mechanical stimulation does not increase the reactivity of a normal fetus. They explain the often observed increase in fetal activity as a spontaneous change of a physiological nature in the fetal sleep-arousal state due to the prolonged period of observation.

These findings are in agreement with those of others [5] using electrical stimulation. This consistently causes short lasting respiratory movements but the sleep-arousal state of the fetus is not altered.

We asked the following questions:

1. Can the fetus be aroused from a state of sleep by mechanical stimulation, i.e. be shifted into a state of increased activity?

2. Is external mechanical stimulation of the fetus with abnormal CTG or nonreactive stress test capable of throwing further light on the fetal state?

\section{Materials and method}

83 observations of fetuses were made in 68 pregnancies. The external CTG was recorded either with suction electrodes (abdominal ECG) or 


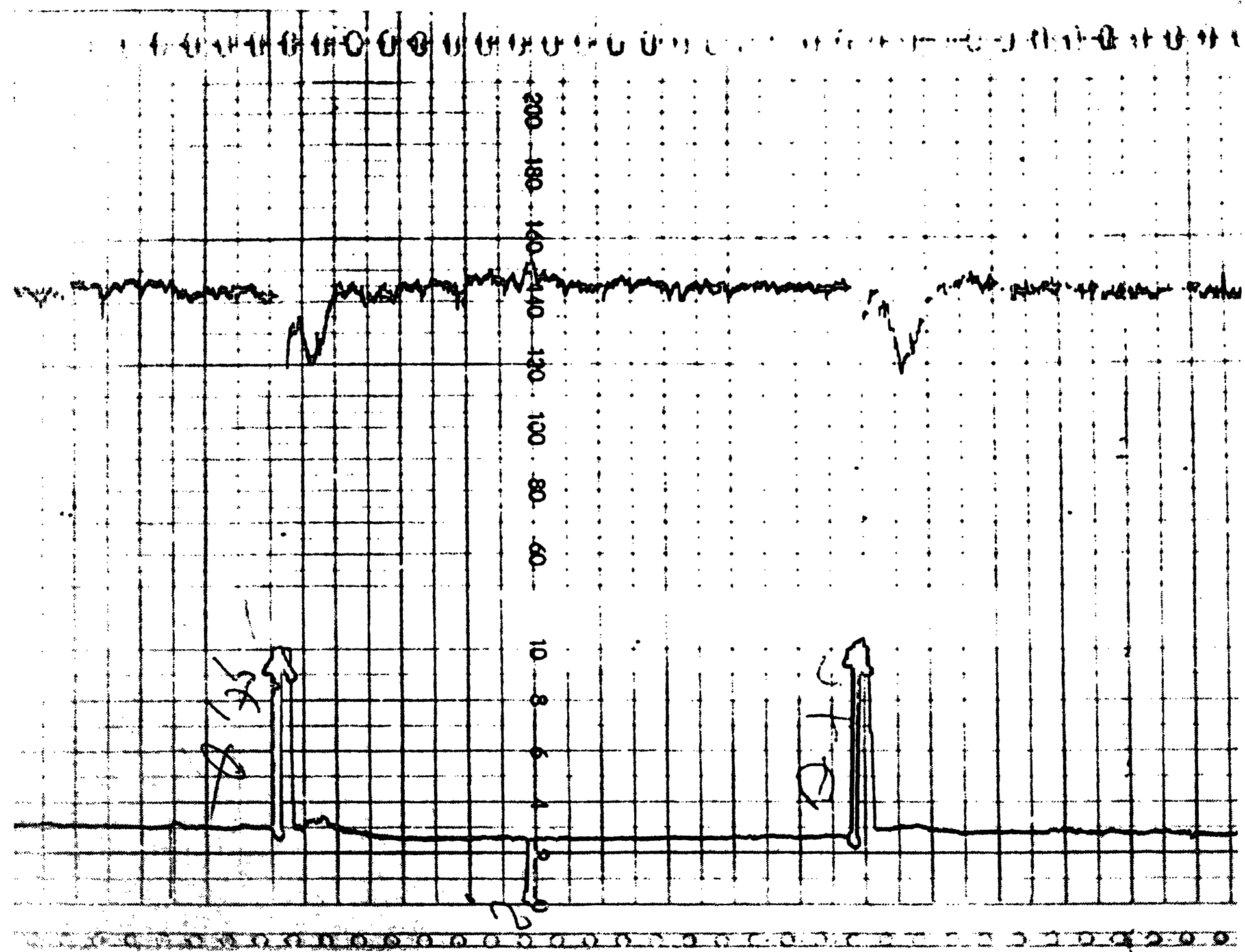

Fig. 1. Case No.62. Severe hypertonia induced by pregnancy with asymetrical retardation of the fetus. Both CTGs show 6 points on the FISCHER scale. Fig. 1 a. 35 th week of gestation. The fetus responds promptly with slight deceleration of $25 \mathrm{bpm}$ lasting 1 minute.

Symbols used:

A thick line underneath the curve of uterine pressure = respiratory movements, not evaluated in this study.

P A thick arrow above the same curve $=5$ seconds of mechanical stimulation of the fetus.

- A thick interrupted line above the curve $=$ marks the statistical control, no stimulation.

Notes in italics during the recordings:

st. = stimulation

n. = marking without stimulation

$\varnothing \quad=$ no fetal movement

$\cdot+,++,+++=$ one or more fetal movements in response to stimulation

DOPPLER ultrasound (sonotachocardiogram). The HEWLETT-PACKARD CARDIOTOCOGRAPH 8030 was used. Fetal movements were observed simultaneously and visually using ultrasound B (SONODIAGNOSTIC R, PHILIPS) and were recorded on the cardiotocogram by pressing a key.

Recordings were made between 7 and 9 p.m., i.e. 1-3 hours after the evening meal. The woman lay partially on her side or completely so, if she so desired. A supine position was also acceptable. In some cases the position of the patient changed during the recording without any effect on the CTG or the fetal state. No signs of a vena cava syndrome were ever observed.

The age of the fetuses was between 32 and 42 gestational weeks. The average time of observation 


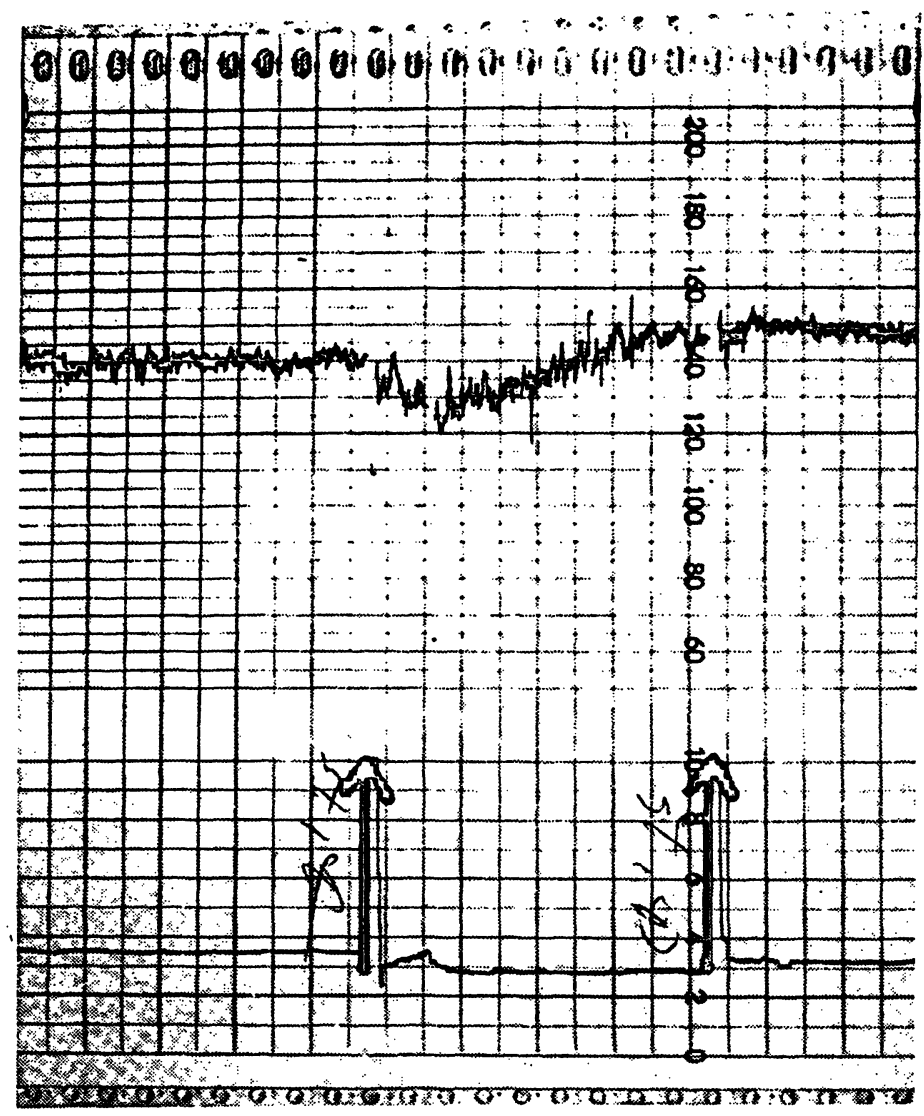

Fig. 1b. 36th week of gestation. Response to the first stimulation is a slight deceleration of $20 \mathrm{bpm}$ lasting 2.5 minutes. No response to the second stimulation. Primary ceasarean section in the 37 th week. Male, $1970 \mathrm{~g}$, $52 \mathrm{~cm}$, APGAR 8/8, pHUA 7.3. Favourable development.

was 56 minutes, the range being 25 to $120 \mathrm{~min}$ utes. In one case only, we interrupted measurements after 16 minutes, since the fetus was heavily damaged and we did not want to endanger it further.

Mechanical stimulation consisted of forcefully shaking the fetal head for 5 seconds by hand controlled by ultrasound. Stimulation was recorded on the uterine pressure curve of the CTG. Fetal movements, accelerations and decelerations of the cardiac frequency were considered to be due to the stimulation if they occurred within 5 seconds after the end of the stimulation.

In addition a 5 second mark was made on the CTG without being followed by stimulation. This mark served as a statistical control. We evaluated the same fetal reactions as those following stimulation, if they occurred within 5 seconds after the end of the mark. The $\mathrm{X}$ square test was used for statistical evaluation. A p $<0.05$ was considered to indicate statistical significance.
An acceleration was considered to have occurred if the heart rate was raised by $15 \mathrm{bpm}$ for at least 15 seconds. Deceleration' was separated into 2 groups. In one the typical spiked Dip 0 were seen. In the other deceleration was variable and is normally found only during labor or fetal movements [8]. This is shown in Figs. 1, $1 \mathrm{a}, 1 \mathrm{~b}, 2$ and 3. These decelerations were taken into account only if the heart rate dropped by at least $15 \mathrm{bpm}$ for a minimum of 20 seconds.

Only combined movements of the trunk and extremities were considered as fetal body movements. Occasional movements of one extremity only and respiratory movements were not taken into account.

The fetal state of sleep-arousal was judged as described by JUNGE [6].

NREM sleep occurred when the oscillation amplitude in the CTG was smaller than in the two other states and when there was no fetal movement [15](Fig.4). Entry into the phase of REM sleep was considered to occur when larger oscillation amplitudes and irregularly occurring accelerations, caused by fetal body movements, were registered (Figs. 4 and 5).

The fetus was considered to be "awake" when motor activity was high and when the CTG showed varied sequential accelerations with an elevated basal rate (Fig. 5).

The reliability of this division into sleep-arousal states by this technique will be discussed later.

Since the oscillation amplitudes, accelerations and fetal movements are all altered during fetal distress the fetal sleep-arousal state was evaluated for a normal CTG only. This, we believe to be impossible for a pathological CTG. A score of 8 or more points according to FISCHER [3] was taken to be the criterion for a normal CTG. In all these CTGs a normal nonstress test was also observed, i.e. a minimum of 4 accelerations of $15 \mathrm{bpm}$ and 15 second duration occurred during 20 minutes of recording. Hence a CTG was considered pathological when it had fewer than 7 points in the FISCHER score. In 83 recordings 17 pathological CTGs were found in 15 pregnancies. The following evaluations were made:

1. With normal CTG a change in the sleep-arousal state of the fetus was looked for after mechanical stimulation. 


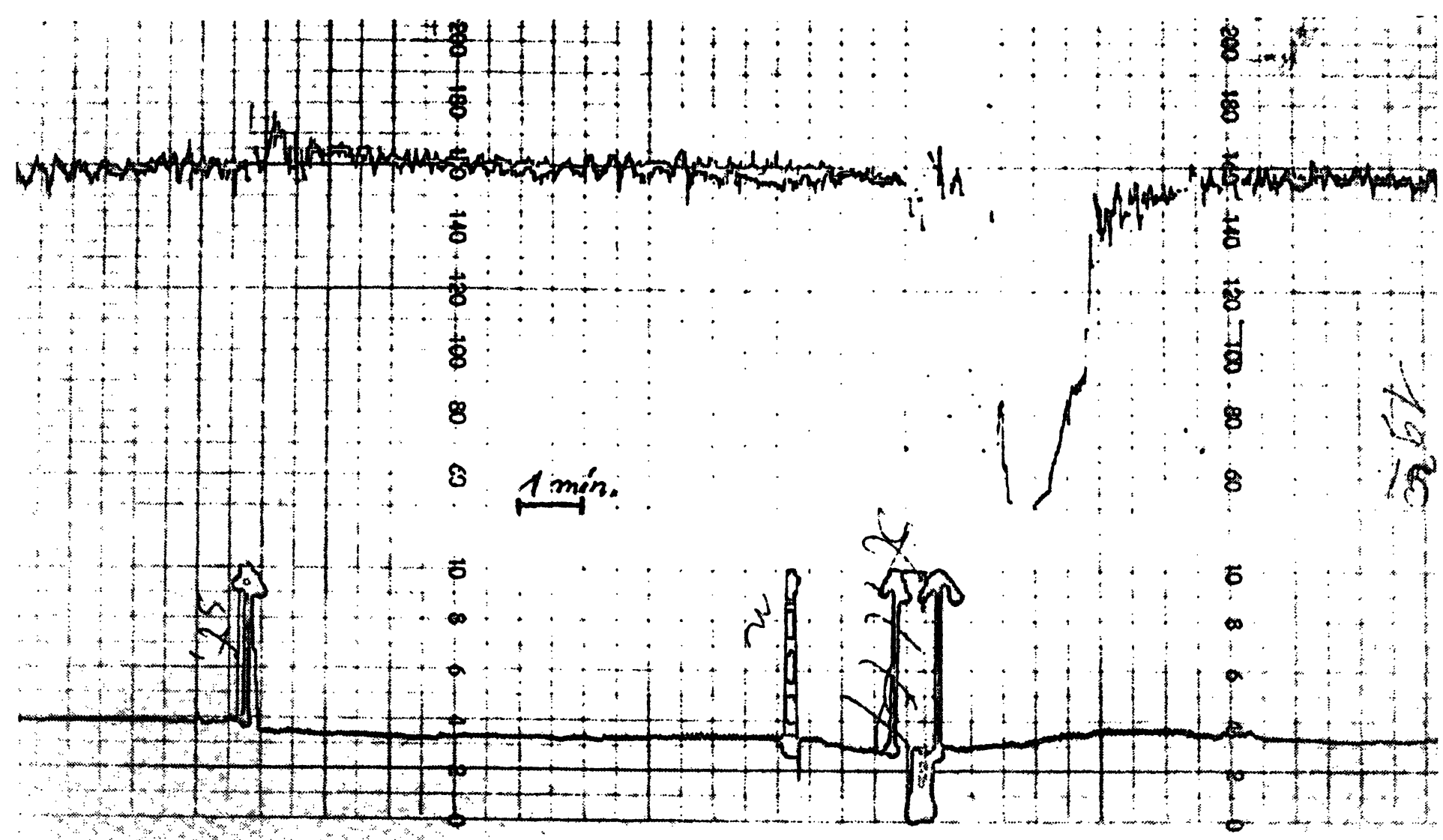

Fig. 2. Case No. 36. Severe intrauterine growth retardation. 35th week. CTG 6 points on FISCHER scale.

Response to first stimulus (left in the CTG) is an acceleration. Two movements follow the second stimulus. The response to the third, shortly following, stimulation is a profound deceleration below $50 \mathrm{bpm}$. Delivery occurred 3 days later by caesarean section. Boy, $1100 \mathrm{~g}$, pronounced dystrophy APGAR score 8/9, $\mathrm{pH}_{\mathrm{UA}}$ 7.26. Died on the 6th day (infection).

Tab.I. Changes in the fetal sleep-arousal state by mechanical stimulation.

\begin{tabular}{|c|c|c|c|c|c|c|}
\hline \multirow[b]{2}{*}{$\begin{array}{l}5 \text { seconds of } \\
\text { mechanical stimulation }\end{array}$} & \multirow{2}{*}{$\begin{array}{l}\begin{array}{l}\text { Fetal state before } \\
\text { stimulation }\end{array} \\
\text { NREM } \\
1\end{array}$} & \multirow{2}{*}{$\begin{array}{l}\text { Number of simuli } \\
92\end{array}$} & \multicolumn{4}{|c|}{$\underset{\mathrm{n}}{\text { Fetal state }} \underset{\%}{\text { after stimulation }}$} \\
\hline & & & $\begin{array}{l}\text { NREM } \\
\text { REM } \\
\text { Arousal }\end{array}$ & $\begin{array}{r}80 \\
6 \\
6\end{array}$ & $\begin{array}{r}87.0 \\
6.5 \\
6.5\end{array}$ & Statistical difference \\
\hline & $\begin{array}{l}\text { REM } \\
2\end{array}$ & 132 & $\begin{array}{l}\text { REM } \\
\text { NREM } \\
\text { Arousal }\end{array}$ & $\begin{array}{l}124 \\
- \\
8\end{array}$ & $\begin{array}{l}93.9 \\
- \\
6.1\end{array}$ & $\begin{array}{l}1-4 \mathrm{p}<0.025 \\
2-5 \mathrm{n} . \mathrm{s} \\
3-6 \mathrm{p}<0.01 \\
\end{array}$ \\
\hline & $\begin{array}{l}\text { Sum } \\
3\end{array}$ & 224 & $\begin{array}{l}\text { Sleep } \\
\text { Arousal }\end{array}$ & $\begin{array}{r}210 \\
14\end{array}$ & $\begin{array}{r}93.7 \\
6.3\end{array}$ & $\begin{array}{l}1-2 \text { n.s. } \\
4-5 \text { n.s. }\end{array}$ \\
\hline & $\begin{array}{l}\text { Fetal state before } \\
\text { control signal }\end{array}$ & Number of controls & \multicolumn{4}{|c|}{$\begin{array}{c}\text { Fetal state after control signal } \\
\text { n } \%\end{array}$} \\
\hline \multirow[t]{3}{*}{$\begin{array}{l}\text { Time signal of } 5 \text { seconds } \\
\text { without stimulation }\end{array}$} & $\begin{array}{l}\text { NREM } \\
4\end{array}$ & 69 & $\begin{array}{l}\text { NREM } \\
\text { REM } \\
\text { Arousal }\end{array}$ & $\begin{array}{r}67 \\
-\quad 2\end{array}$ & $\begin{array}{r}97.1 \\
2.9 \\
-\end{array}$ & \\
\hline & $\begin{array}{l}\text { REM } \\
5\end{array}$ & 110 & $\begin{array}{l}\text { REM } \\
\text { NREM } \\
\text { Arousal }\end{array}$ & $\begin{array}{l}108 \\
- \\
2\end{array}$ & $\begin{array}{c}98.2 \\
- \\
1.8\end{array}$ & \\
\hline & $\begin{array}{l}\text { Sum } \\
6\end{array}$ & 179 & $\begin{array}{l}\text { Sleep } \\
\text { Arousal }\end{array}$ & $\begin{array}{r}177 \\
2\end{array}$ & $\begin{array}{r}98.9 \\
1.1\end{array}$ & \\
\hline
\end{tabular}




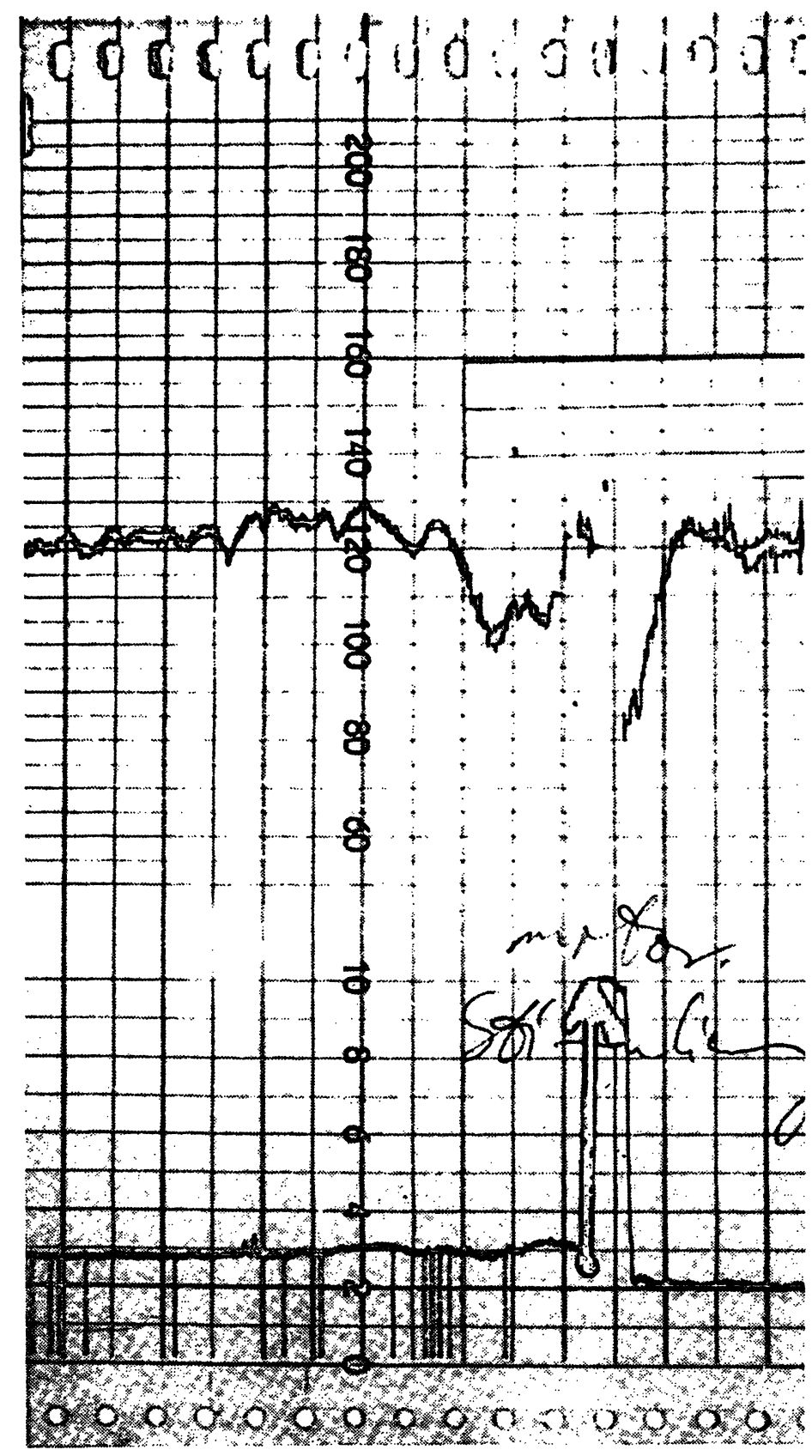

Fig. 3. Case No. 5. 24 year-old primipara. Fetal movements decrease in the 40th week, little amniotic fluid, pathological CTG, 4 points according to FISCHER.

Following a spontaneous deceleration, another one, more pronounced, appeared on mechanical stimulation. Ceasarean section. Male, $3000 \mathrm{~g}$, APGAR score 4/6, $\mathrm{pH}_{\mathrm{UA}}$ 7.08. Died on day 5 (brain damage, cerebral softening).

2. The occurrence of body movements, accelerations and decelerations of the heart rate as a short lasting response to mechanical stimulation was assessed.

This was done separately for fetal REM and NREM sleep in normal CTG. Statistical control recordings of spontaneous fetal responses were also included.
For pathological CTGs we evaluated only the short-lasting fetal responses to mechanical stimulation without regards to sleep-arousal state.

\section{Results}

Tab. I summarizes for normal CTGs the frequency at which the fetal sleep-arousal state was unaltered by mechanical stimulation. This occurred in $87 \%$ of cases in NREM sleep, in $6.5 \%$ a change into REM sleep occurred and in $6.5 \%$ arousal was observed. Stimulation during REM sleep maintains the latter in $93.9 \%$ while in $6.1 \%$ arousal occurred. No change-over into the less active motor phase of NREM phase was observed. The differences between the two sleep states after mechanical stimulation are not statistically significant.

Tab. I also shows changes in the sleep-arousal state that occur without stimulation. In NREM sleep a change into REM sleep occurred in $2.9 \%$ (no direct change into arousal). The arousal state was observed in $1.8 \%$ in REM sleep (no change into NREM sleep).

Spontaneous changes in the sleep-arousal state in NREM and REM sleep are equally frequent. A more active motor phase (REM sleep and arousal) after mechanical stimulation is $13 \%$ more frequent from NREM state than that which occurs spontaneously (2.9\%). This difference is statistically significant. The change from REM sleep to arousal after stimulation does not occur more frequently $(6.1 \%)$ than spontaneously $(1.8 \%)$.

Altogether the "arousal" of the fetus occurs significantly more frequently $(6.3 \%)$ after stimulation than spontaneously $(1.1 \%)$. Hence it is possible to arouse the fetus occasionally by mechanical stimulation.

Tab. II summarizes the short term response to mechanical stimulation. With normal CTG the fetal response was evaluated only once according to the most important criterion so that the sum total of tests never exceeded $100 \%$. Following stimulation in NREM sleep a dip 0 occurred in $4.4 \%$ (additional body movements in one case), and in REM in $5.3 \%$ ( 2 cases with additional movements). 


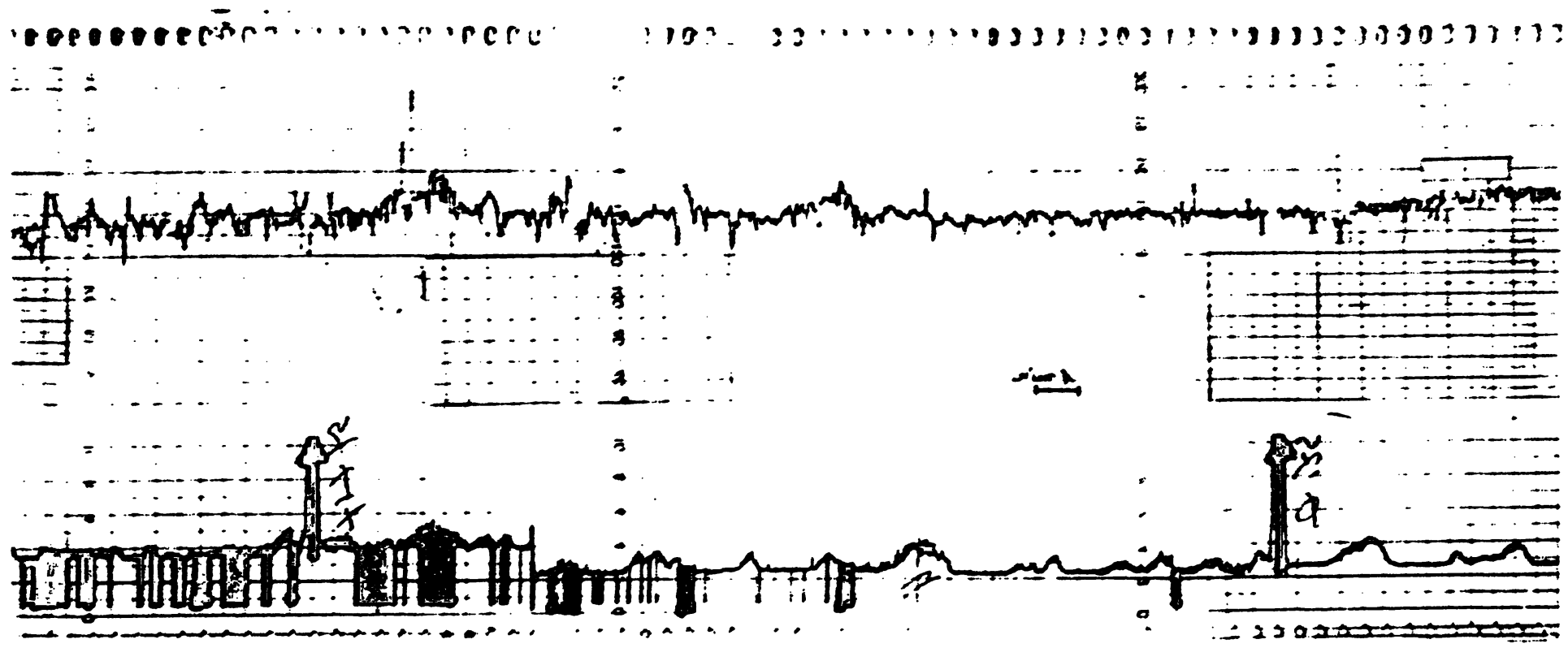

Fig. 4. Case No.56. 28 year-old primipara. Pregnant after hormone treatment for sterility. Slight intrauterine growth retardation. 40 th week of pregnancy. CTG 8 points on FISCHER scale.

Left half show the CTG with a small oscillation amplitude and absent accelerations indicating fetal NREM sleep. Only one movement within the 15 minutes shown. No respiratory movements. No response to mechanical stimulation. In the center of the figure the spontaneous change from NREM to REM sleep is shown. An increase in the oscillation amplitude and the appearance of accelerations are shown. The fetus responds with movements to mechanical stimulation. Spontaneous delivery two days later. Female, $2620 \mathrm{~g}, 49 \mathrm{~cm}$. A PGAR score 9/10. Normal neonatal period. pH UA 7.18

Tab. II. The frequency of fetal body movements, accelerations or decelerations after mechanical stimulation of the fetus or after control signal without stimulation in dependence on the CTG evaluation.

\begin{tabular}{|c|c|c|c|c|c|c|c|c|}
\hline \multirow{2}{*}{$\begin{array}{l}\text { Stimulation } \\
\text { or control }\end{array}$} & \multirow{2}{*}{$\begin{array}{l}\text { CTG } \\
\text { evaluation }\end{array}$} & \multirow[t]{2}{*}{ Fetal state } & & \multicolumn{5}{|l|}{ Fetal reactions } \\
\hline & & & & $\begin{array}{l}\text { Decelerations } \\
\text { of differing } \\
\text { forms }\end{array}$ & Dip 0 & $\begin{array}{l}\text { Body } \\
\text { move- } \\
\text { ments }\end{array}$ & $\begin{array}{l}\text { Acceler- } \\
\text { ations } \\
\text { only }\end{array}$ & $\begin{array}{l}\text { No } \\
\text { reac- } \\
\text { tions }\end{array}$ \\
\hline \multirow{2}{*}{$\begin{array}{l}5 \text { seconds } \\
\text { mechanical } \\
\text { stimulation } \\
\text { of fetus }\end{array}$} & \multirow[t]{2}{*}{$\begin{array}{l}\text { normal } \\
1\end{array}$} & $\begin{array}{l}\text { NREM } \\
3\end{array}$ & $\begin{array}{cc}\mathrm{n} & 92 \\
\% & 100.0\end{array}$ & $\overline{-}$ & $\begin{array}{l}4 \\
4.4\end{array}$ & $\begin{array}{l}25 \\
27.2\end{array}$ & $\begin{array}{l}34 \\
36.9\end{array}$ & $\begin{array}{l}29 \\
31.5\end{array}$ \\
\hline & & $\begin{array}{l}\text { REM } \\
4\end{array}$ & $\begin{array}{ll}\mathrm{n} & 132 \\
\% & 100.0\end{array}$ & - & $\begin{array}{l}7 \\
5.3\end{array}$ & $\begin{array}{l}60 \\
45.4\end{array}$ & $\begin{array}{l}32 \\
24.3\end{array}$ & $\begin{array}{l}33 \\
25.0\end{array}$ \\
\hline \multirow{2}{*}{$\begin{array}{l}5 \text { second } \\
\text { signal } \\
\text { without } \\
\text { stimulation }\end{array}$} & \multirow[t]{2}{*}{ normal } & $\begin{array}{l}\text { NREM } \\
5\end{array}$ & $\begin{array}{cc}\mathrm{n} & 69 \\
\% & 100.0\end{array}$ & $\begin{array}{l}- \\
-\end{array}$ & $\begin{array}{l}- \\
-\end{array}$ & $\begin{array}{l}1 \\
1.5\end{array}$ & $\begin{array}{l}1 \\
1.5\end{array}$ & $\begin{array}{l}67 \\
97.0\end{array}$ \\
\hline & & $\begin{array}{l}\text { REM } \\
6\end{array}$ & $\begin{array}{ll}\mathrm{n} & 110 \\
\% & 100.0\end{array}$ & $\overline{-}$ & $\overline{-}$ & $\begin{array}{l}11 \\
10.0\end{array}$ & $\begin{array}{l}5 \\
4.5\end{array}$ & $\begin{array}{l}94 \\
85.5\end{array}$ \\
\hline $\begin{array}{l}5 \text { seconds } \\
\text { mechanical } \\
\text { stimulation } \\
\text { of fetus }\end{array}$ & $\begin{array}{l}\text { pathological } \\
2\end{array}$ & $\begin{array}{l}\text { not differentiated } \\
7\end{array}$ & $\begin{array}{cc}n & 63 \\
\% & 100.0\end{array}$ & $\begin{array}{l}12 \\
19.0\end{array}$ & $\begin{array}{l}14 \\
22.2\end{array}$ & $\begin{array}{c}9 \\
14.3\end{array}$ & $\begin{array}{l}10 \\
15.9\end{array}$ & $\begin{array}{l}18 \\
28.6\end{array}$ \\
\hline $\begin{array}{l}\text { Statistical } \\
\text { differences }\end{array}$ & $\begin{array}{l}3-5 \\
4-6 \\
1-2\end{array}$ & $\begin{array}{l}p<0.001 \\
p<0.001 \\
p<0.001\end{array}$ & & $\begin{array}{l}3-4 \text { n.s. } \\
5-6 \mathrm{p}<0.025 \\
\text { (without decele }\end{array}$ & rations & differing & rms) & \\
\hline
\end{tabular}




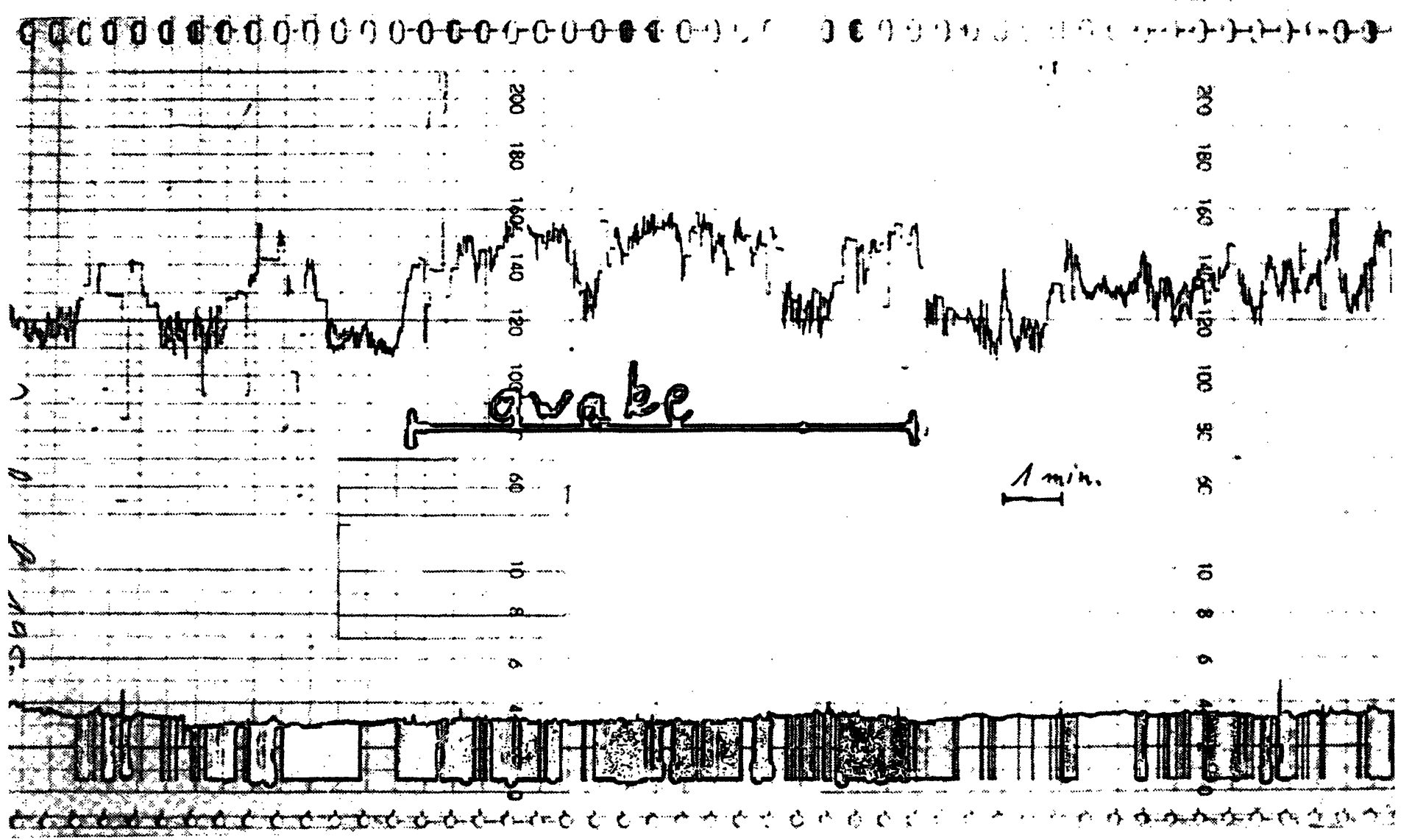

Fig. 5. Case No. 57. Gestational diabetes with slight growth retardation. 38th week. Normal CTG, 8 FISCHER points. Spontaneous change from REM sleep to arousal with an increase in motor activity of the fetus, a rise in the basic frequency and confluent accelerations. Followed again by a spontaneous change into REM sleep. Two days later induction of delivery with oxytocin infusion. Spontaneous delivery. Male, $2590 \mathrm{~g}, 49 \mathrm{~cm}$, APGAR score $9 / 10$. Normal neonatal period.

Fetal movements following stimulation in NREM sleep were found in $27.2 \%$ and in REM sleep in $45.4 \%$. This was nearly always accompanied by acceleration of the fetal heart rate. The difference is not statistically significant.

Only heart rate accelerations in the CTG after stimulation were found in $36.9 \%$ during NREM and in $24.3 \%$ during REM sleep. No reactions were found in $31.5 \%$ in NREM sleep and in $25.0 \%$ in REM sleep.

In contrast spontaneously no dip 0 occurred in either sleep phase. Movements and accelerations, $1.5 \%$ each are characteristic for NREM sleep. Movements occur more frequently (10\%) in REM sleep. This is significantly different. The rate of occurrence of dip 0 , movements and acceleration in both states of sleep is statistically more frequent after mechanical stimulation than that found spontaneously.

Decelerations after mechanical stimulation were only observed in pathological CTGs. They resem- bled variable decelerations (Figs. $1 \mathrm{a}, 1 \mathrm{~b}, 2,3$ ). Since these decelerations contributed to the changes in the CTG they were not included when evaluating pathological CTGs for statistical comparisons with normal ones.

The frequency of occurrence of responses with dip 0 after stimulation in pathological CTGs $(22.2 \%)$ is about five fold higher than in normal CTG (4.4-5.3\%).

Fetal responses to mechanical stimulation as body movements or accelerations are about half as frequent as in normal CTG. The percentage of fetuses without any responses is the same for normal and pathological CTG: 25\%-31.5\% against $28.6 \%$.

\section{Discussion and conclusion}

In $90 \%$ of cases mechanical stimulation of the fetus causes no change in its state. During NREM sleep this remains unaltered in $87 \%$ following 
stimulation. The percentage for REM sleep was $93.9 \%$.

This, however, is valid only if the fetus was not in distress and if it had a normal CTG, and is in agreement with the results of others [5, 14]. Actual arousal by stimulation during NREM sleep was found in only $6.5 \%$, in REM sleep in $6.1 \%$. This is statistically more frequent than arousal occurring spontaneously without stimulation, when it occurs in only $1.8 \%$.

However, mechanical stimulation results in $68.5 \%$ of NREM and $75 \%$ REM sleep in short lasting fetal responses (dip 0 , movement or only acceleration of the heart rate) interrupting for several seconds the continuity of the fetal state. Our technique cannot distinguish between the different states of arousal [13]. It is also not possible to distinguish the REM sleep in this short period from a short lasting state of arousal using body movements which normally accompany accelerations of the heart rate. This state of arousal has been termed "state 4" [13] in the newborn, which is awake with open eyes and head movements, and movements of the torso and extremities.

This impossibility was discussed by JUNGE [6] who hence mentions "state $2 / 4$ ". Such a distinction can be made using polygraphic recordings in the animal fetus [5] and in human newborns [13] - for further references see [6] - . We consider the analogical conclusions regarding the regulation of the fetal sleep-arousal state sufficiently persuasive as they apply to the human fetus as judged from fetal movements and the CTG. We evaluated only clear arousal states with increased motor activity as compared to REM sleep and judged the overlapping accelerations in the CTG as such. Fetal respiratory movements were also taken into consideration but were not evaluated in this study. All other periods of movement with acceleration after fetal stimulation, if they occurred within the typical REM sleep picture, were included in this picture. We consider it as unlikely, but cannot exclude it, that after stimulation in REM sleep the fetus is transiently aroused during movements and is then promptly returned to the sleeping state. This does not affect the conclusions concerning CTG evaluation.
On the whole, we found that about $30 \%$ of fetuses do not react to mechanical stimulation. This is the same for normal and pathological CTG. We could not confirm the claim $[3,8]$ that the absence of a fetal reaction to mechanical stimulation indicates a pathological state. We could not distinguish the different sleep-arousal phases in the fetus during fetal distress using our technique.

In pathological CTG the fetus responds with decelerations in $41.2 \%$. Some of these showed different forms and were more or less accentuated and were thus similar to the variable decelerations during labor. They occurred in $19.0 \%$. Their cause could not be determined.

It is possible that

- mechanical stimulation simultaneously evokes uterine contractions (they could be demonstrated in 2 out of 12 cases),

- direct or indirect effect on the umbilical cord, occurred,

- this is a typical cardiac reaction of an irritated fetus with limited compensatory capacity (placental insufficiency).

As for as we know this has not been reported in the literature. However, the response of the stimulated fetus with dip 0 occurred with $22.2 \%$ in the pathological CTG significantly more frequently than in the normal CTG (4.8\%, REM + NREM).

Our own data and those of others $[2,10,11]$ suggest that physiological NREM sleep may occasionally last longer than 30 minutes. Neither respiratory nor body movements need occur during that time [11]. This signifies a pathological result of the nonstress test on the FISCHER score (fewer than 8 points) in the external antenatal CTG if the fetal state is not taken into account. No accelerations are found in the CTG and the oscillation amplitude (macrofluctuations) falls below $10 \mathrm{bpm}$ (narrowing of the band width).

We suggest that in order to differentiate between physiological sleep (NREM) and fetal distress with limited compensatory capacity (both lack accelerations, show diminished oscillation amplitudes) one should apply both mechanical stimulation (1-3 3 for 5 seconds each of the head, $[1,3$, $8]$ and a prolongation of the time of recording by at least 30 minutes $[2,10,11]$. The occurrence of 
decelerations that do not belong to dip 0 indicate a pathological CTG. Repeated dip 0 occurrence suggests increased attention to such a case. As far as the CTG permits this, we can exclude fetal distress if NREM sleep is changed into a more active state (REM sleep or arousal). If there is no fetal reaction to mechanical stimulation further. CTG recordings during the next 30 to 60 minutes will tell whether there is physiological alternation

\section{Summary}

Several authors have recommended $[1,3,8,12]$ that the fetus be mechanically stimulated if the abdominal pregnancy CTG shows no accelerations. One expects the fetus to show a motor response to mechanical stimulation. Fetal movements expressed as accelerations in the abdominal CTG are considered to reflect "arousal" of the previously asleep fetus and are thought to be normal. An absence of such a response in considered by some as a sign of pathological fetal changes [3, 8, 12]. Others, however, have found that the normal non-stressed fetus need not change its sleep-arousal state after mechanical stimulation $[5,14]$.

An attempt was made to clarify this in the present work. We studied the CTG recordings and the ultrasound pictures in 63 pregnancies in a total of 83 cases for an average of 56 minutes. Fetal movements were marked by pressing a lever on the labor pressure chart. The fetus was mechanically stimulated by shaking its head manually for 5 seconds. Control recordings were also made, when the fetus was not so stimulated.

The following results were obtained:

1. With a normal CTG (reactive nonstress test, FISCHER score 8-10 points)

Mechanical stimulation led to no changes in $87 \%$ of NREM sleep and in $93.9 \%$ of REM sleep. A change to a more active state (REM sleep + arousal) due to stimulation was found in $13 \%$ of NREM sleep, which is significantly more frequent than the $2.9 \%$ found when no stimulation occurred. A change from REM sleep to arousal was found in $6.1 \%$, not significantly different from $1.8 \%$ found without stimulation.

Short-lasting reactions to mechanical stimulation included movements, acceleration of fetal heart rate and dip 0 . These reactions were equally frequent in REM and NREM sleep, i.e. $75 \%$ and $68.5 \%$ respectively.

Keywords: CTG, fetal movements, mechanical stimulation. between sleep and arousal or not. The exclusive occurrence of a single acceleration as the sole fetal response to mechanical stimulation cannot clarify the situation.

If we proceed along these lines then the demand for a consideration of the fetal sleep-arousal state $[2,6,7,10,11]$ for an assessment of the fetal CTG is sufficiently taken into account.

These reactions occurred by chance less frequently, in $14.5 \%$ of cases in REM and in $3 \%$ of cases in NREM sleep (Tab. II). The occurrence is significantly higher in REM than in NREM sleep.

2. In a pathological CTG (FISCHER score 7 points or less) our technique does not permit us to distinguish the different sleep-arousal states. Only the shortlasting response to mechanical stimulation of the fetus was hence evaluated. Mechanical stimulation resulted in a fetal response in $19 \%$ with decelerations of variable expression (Figs. 1a, 1 b, 2, 3) similar to the variable decelerations observed during labor.

These decelerations occurred only together with other signs of fetal distress in the CTG.

The rate of dip 0 occurrence following mechanical stimulation with pathological CTG present was significantly higher $(22.5 \%)$ than when the CTG was normal $(4.4-5.3 \%)$. The same percentage of cases with normal or pathological CTG showed no reaction at all, $28.6 \%$ for pathological and $25-31.5 \%$ for normal CTG.

We conclude

1. that the absence of a fetal response to mechanical stimulation gives no information regarding the state of the fetus;

2. that the occurrence of variable decelerations in response to mechanical stimulation of the fetus is a pathological sign. Hence the mechanical stimulation of the fetus in the non-reactive nonstress test may be of some value;

3. that a change from a sleep phase into an arousal phase following mechanical stimulation of the fetus is only rarely attained.

\section{Zusammenfassung}

Reaktionen des Feten auf äußere mechanische Stimulation

Werden im Rahmen der fetalen Überwachung in der Schwangerschaft im abdominalen CTG keine Akzelerationen gefunden, so wird von einigen Autoren empfohlen, den Feten mechanisch zu stimulieren $[1,3,8,12]$. Es wird erwartet, daß im Anschluß an die Stimulation der Fet motorisch aktiv wird. Der Nachweis der fetalen
Körperbewegungen, die sich im abdominalen CTG als Akzelerationen ausdrücken, wird als ,aufwachen“ des zuvor schlafenden Feten und normale Reaktion gewertet. Ein Ausbleiben dieser Reaktion wird von einigen Untersuchern als Ausdruck eines pathologischen fetalen Zustandes angesehen [3, 8, 12].

Demgegenüber haben andere Untersucher gefunden, daß auch der normale Fet, der sich nicht unter den Bedingun- 
gen eines Distress befindet, durch die mechanische Stimulation seinen Schlaf-Wach-Zustand nicht ändert [5, 14]. Zur Klärung dieser Problematik wollten wir mit eigenen Untersuchungen beitragen.

Bei 63 Schwangeren haben wir insgesamt $83 \mathrm{mal}$ den Feten durchschnittlich 56 Minuten lang mittels Ultraschall-B-Bild beobachtet und gleichzeitig das abdominale CTG geschrieben. Die fetalen Körperbewegungen wurden über eine Drucktaste an der Wehendruckkurve markiert. Die mechanische Stimulierung des Feten erfolgte jeweils manuell über 5 Sekunden durch Schüttelbewegungen am Kopf. Zur statistischen Abklärung des Auftretens fetaler Reaktionen als spontane Vitalitätsäußerungen, die nicht Folge einer Stimulierung sind, wurden in die Registrierkurven auch willkürlich Markierungen eingetragen, ohne daß eine Stimulierung des Feten erfolgte.

\section{Folgende Ergebnisse wurden gewonnen:}

1. Bei normalem CTG (reak tiver nonstress test, FISCHERScore 8-10 Punkte)

Beim Vergleich der Schlaf-Wach-Zustände der Feten vor und nach mechanischer Stimulation zeigte sich, daß der NREM-Schlaf in $87,0 \%$ und der REM-Schlaf in $93,9 \%$ beibehalten wurde. Der Wechsel in einen aktiveren fetalen Verhaltenszustand (REM-Schlaf + Wach-Zustand) durch die Stimulation trat beim NREM-Schlaf mit $13 \%$ jedoch signifikant häufiger auf, als das spontan (Markierung ohne Stimulation) in 2,9\% beobachtet wurde. Der Übergang vom REM-Schlaf in den Wachzustand wurde nach der Stimulation in 6,1\% beobachtet und war damit nicht signifikant häufiger als der spontane Wechsel ohne Stimulation mit 1,8\%.

Als kurzfristige Reaktionen auf die mechanische Stimulation hin beobachteten wir Körperbewegungen, Akzelerationen der fetalen Herzfrequenz und Dip 0 . Insgesamt wurden diese Reaktionen im REM-Schlaf mit $75,0 \%$ etwa gleich häufig wie im NREM-Schlaf mit $68,5 \%$ beobachtet.

Zufällig wurden diese Reaktionen nach den Markierungen ohne Stimulation wesentlich seltener beobachtet, im REM-Schlaf nur insgesamt in $14,5 \%$ und im NREM-Schlaf in 3,0\% (Tab. II). Dabei ist das häufigere Auftreten dieser Reaktionen im REM-Schlaf gegenüber dem NREM-Schlaf ebenfalls signifikant.

2. Bei pathologischem CTG (FISCHER-Score 7 Punkte und weniger) können die einzelnen fetalen SchlafWach-Zustände mittels der von uns angewendeten Methodik nicht sicher unterschieden werden. Für diese Fälle wurden nur die kurzfristigen Reaktionen auf die mechanische Stimulation des Feten ausgewertet. Als Folge der mechanischen Stimulation reagierten die Feten in 19,0\% mit Dezelerationen unterschiedlicher Ausprägung (Figs. 1 a, 1 b, 2, 3), die den variablen Dezelerationen gleichen, die bei Wchentätigkeit gesehen werden.

Das Auftreten dieser Dezelerationen fanden wir nur im Zusammenhang mit weiteren Hinweisen in CTG für einen fetalen Distress.

Die Rate der Dip 0 nach mechanischer Stimulation bei pathologischem CTG war mit $22,5 \%$ signifikant höher als nach Stimulation des Feten mit normalem CTG (4,4-5,3\%). Der Prozentsatz von Feten, die gar keine Reaktion auf die mechanische Stimulation zeigten, war zwischen den Fällen mit pathologischem CTG $(28,6 \%)$ und den Fällen mit normalem CTG $(25,0 \%-31,5 \%)$ nicht unterschiedlich.

Als Schlußfolgerungen aus dieser Studie können wir ziehen:

1. Das Ausbleiben einer fetalen Reaktion auf eine mechanische Stimulation sagt nichts über das Wohlbefinden des Feten aus.

2. Das Auftreten von Dezelerationen unterschiedlicher Ausprägung als Folge einer mechanischen Stimulation des Feten muß als pathologisch gewertet werden. Damit kommt der mechanischen Stimulation bei nicht reaktivem nonstress Test ein diagnostischer Wert $\mathrm{zu}$.

3. Der Übergang aus einer Schlafphase in die Wachphase durch mechanische Stimulation des Feten wird nur selten erreicht.

Schlïsselwörter: CTG, fetale Bewegungen, mechanische Stimulierung.

\section{Résumé}

\section{Réponse fœtale aux stimuli mécaniques externes}

Plusieurs auteurs $[1,3,8,12]$ ont recommandé de stimuler mécaniquement le fœtus lorsque le C.T.G. abdominal en cours de grossesse ne montre pas d'accélération.

On attend du fœtus qu'il manifeste une réponse motrice à la stimulation mécanique. Les mouvements fœtaux exprimés par des accélérations sur le C.T.G. abdominal sont considérés comme le témoin de l'éveil du fœtus précédemment endormi et sont estimés comme normawx. Certains $[3,8,12]$ considèrent l'absence d'une telle réponse comme un signe de pathologie fœtale.

Toutefois, d'autres ont mis en évidence que le fœtus normal, non stressé, ne modifie pas son équilibre veillesommeil après stimulation mécanique $[5,14]$.

Ce travail est une tentative de clarification de ce point.

Nous avons étudié les enregistrements C.T.G. et les films échographiques au cours de 63 grossesses parmi 83 cas au total, pendant une moyenne de 56 minutes.

Les mouvements fœtaux ont été enregistrés sur le diagramme d'activité utérine en appuyant sur une manette.
On a stimulé le fœtus mécaniquement en secovant sa tête manuellement pendant 5 secondes.

Des enregistrements de contrôle on été effectués, sans stimulation fœtale.

On a obtenu les résultats suivants:

1. Lorsque le C.T.G. est normal (non stress test réactif, score de FISCHER égal à 8-10 points), une stimulation mécanique n'entraine pas de modification dans $87 \%$ des cas de sommeil non REM et dans $93,9 \%$ des cas de sommeil REM.

Une évolution vers un état plus actif (sommeil REM + éveil) secondaire à une stimulation a été trouvée dans $13 \%$ des cas de sommeil NREM, ce qui est plus fréquent, de façon significative, que les $2,9 \%$ trouvés en l'absence de stimulation.

L'évolution du sommeil REM vers l'éveil a ćté observée dans $6,1 \%$ des cas ce qui ne diffère pas significativement des $1,8 \%$ trouvés en l'absence de stimulation.

Les réactions brèves à la stimulation mécanique comprennent les mouvements, l'accélération du 
rythme cardiaque fætal et les dip 0. Ces réactions sont également fréquentes au cours du sommeil REM et NREM, c'est à dire respectivement dans $75 \%$ et $68,5 \%$ des cas. Ces réactions surviennent au hasard moins fréquemment, dans $14,5 \%$ des cas au cours du sommeil REM et dans $3 \%$ des cas au cours du sommeil non REM (Tab. II). La survenue est plus élevée de façon significative au cours du sommeil REM qu'au cours du sommeil non REM.

2. Lorsque le C.T.G. est pathologique (score de FISCHER inférieur ou égal à 7 points), notre technique ne nous permet pas de distinguer les différents états de veille et de sommeil.

En conséquence, seules les réactions brèves à la stimulation mécanique du fœtus on été évaluées.

Dans $19 \%$ des cas:

La stimulation mécanique a entrainé une réponse fœtale à type de décélérations variables (Figs. 1 a, 1 b, 2,3 ), similaires aux décélérations variables observées en cours de travail.

Ces décélérations ne sont survenues qu'en association avec d'autres signes de souffrance fætale sur le C.T.G.
La fréquence des dip 0 survenant après stimulation mécanique lors de C.T.G. pathologiques est plus grande de façon significative $(22,5 \%)$ que lorsque le C.T.G. est normal $(4,4-5,3 \%)$. Le même pourcentage de cas ne montrent pas de réaction que le tracé soit normal ou pathologique, $28,6 \%$ pour les tracés pathologiques et $25-31,5 \%$ pour les tracés normaux.

Nous concluons que:

1. L'absence: de réaction fœtale à une stimulation mécanique ne renseigne pas sur l'état du fœtus.

2. L'apparition de décélérations variables en réponse à une stimulation mécanique du fœtus est un signe pathologique.

Il en découle que la stimulation mécanique du fœtus peut avoir la même valeur au cours des non stress tests non réactifs.

3. Une modification d'une phase du sommeil vers un état d'éveil découlant d'une stimulation mécanique du fœtus n'est obtenue que rarement.

Mots-clés: C.T.G., mouvements fœtaux, stimulation mécanique.

Bibliography

[1] BARRETT, J. M., S. L. SALYER, F. H. BOEHM : The nonstress test: An evaluation of 1000 patients. Amer. J. Obstet. Gynec. 141 (1981) 153

[2] BROWN, R., J. PATRICK: The nonstress test: How long is enough. Amer. J. Obstet. Gynec. 141 (1981) 646

[3] FISCHER, M.: Kardiotokografie. Lehrbuch und Atlas. Thieme, Stuttgart (1976)

[4] HARPER, R. M., T. HOPPENBROUWERS, M. B. STERMAN, D. J. MC GINTY, J. HODGMAN: Polygraphic studies of normal infants during the first six months of life. I. Heart rate and variability as a function of state. Pediat. Res. 10 (1976) 945

[5] JOFFE, S., A. H. JANSEN, B. J. RUSSEL, V. CHERNICK: Respiratory response to somatic stimulation in fetal lambs during sleep and wakefulness. Pfluegers Arch. Eur. J. Physiol. 388 (1980) 143

[6] JUNGE, H. D.: Behavioral states and state related heart rate and motor activity patterns in the newborn infant and the fetus antepartum - A comparative study. I. Technique, illustration of recordings, and general results. J. Perinat. Med. 7 (1979) 85

[7] JUNGE, H. D., H. WALTER: Behavioral states in the fetus near term. J. Perinat. Med. Suppl. 1, 9 (1981) 153

[8] LEE, C. Y., P. C. DIloReTO, B. LOGRAND: Fetal activity acceleration determination for the evaluation of fetal reserve. Obstet. and Gynec. 48 (1976) 19

[9] O'LEARY, J. A., G. C. ANDRINOPOULOS, P. C. GIORDANO: Variable decelerations and the nonstress test: An indication of cord compromise. Amer. J. Obstet. Gynec. 137 (1980) 704
[10] PATRICK, J., W. FETHERSTON, H. VICK, R. VOEGLIN: Human fetal breathing movements and gross fetal body movements at weeks 34 to 35 of gestation. Amer. J. Obstet. Gynec. 130 (1978) 693

[11] PATRICK, J., R. NATAB, B. RICHARDSON: Patterns of human fetal breathing activity at 34 to 35 weeks' gestational age. Amer. J. Obstet. Gynec. 132 (1978) 507

[12] PHELAN, J.P.: Diminished fetal reactivity with smoking. Amer. J. Obstet. Gynec. 136 (1980) 230

[13] PRECHTL, H. F. R., H. G. LENARD: Verhaltensphysiologie des Neugeborenen. In: LINNEWEH, F.: Fortschritte der Pädologie. Springer, Berlin - Heidelberg - New York (1968)

[14] RICHARDSON, B., K. CAMPBELL, L. CARMICHAEL, J. PATRICK: Effects of external physical stimulation on fetuses near term. Amer.J. Obstet. Gynec. 139 (1981) 344

[15] TIMOR-TRITSCH, I. E., L. J. DIER KER, R. H. HERTZ, N. C. DEAGAN, M. G. ROSEN: Studies of antepartum behavioral state in the human fetus at term. Amer. J. Obstet. Gynec. 132 (1978) 524

Received August 6, 1982. Revised November 29, 1982. Accepted March 23, 1983.
Dr. sc. med.Ernst Peter Issel Universitäts-Frauenklinik Leninallee 24 DDR-4020 Halle/S. 